\title{
The toxic stress and its impact on development in the Shonkoff's Ecobiodevelopmental Theorical approach
}

\author{
O estresse tóxico e seu impacto no desenvolvimento na \\ perspectiva da Teoria do Ecobiodesenvolvimento \\ de Shonkoff
}

\author{
Marília Souza Silva BRANCO ${ }^{1}$ \\ ORCID iD 0000-0002-3476-6544 \\ Maria Beatriz Martins LINHARES² \\ ORCID iD 0000-0001-5958-9874
}

\begin{abstract}
Development is characterized by quantitative and qualitative changes that occur in a predetermined sequence. However, development could be affected by adversities, which change its typical course. The present study aimed to carry out a review of the concept of toxic stress, used in the Shonkoff's Ecobiodevelopmental Theory, and to analyze its impact on human development. A search was conducted in the PubMed database, which yielded 12 conceptual articles from 2000 to 2013. The results were categorized into themes. The theory proposed by Shonkoff aims to elucidate the impact of stress on child development, based on other developmental theories. Toxic stress pertains to the prolonged activation of the body as a response to the stress system that can provoke neurobiological and psychological damages. The interventions proposed in the reviewed studies were effective in minimizing the negative effects of this type of stress, as well as in providing support to the caregivers of children.
\end{abstract}

Keywords: Childhood development; Health; Stress.

\section{Resumo}

O desenvolvimento é caracterizado por mudanças quantitativas e qualitativas, que são ordenadas e sequenciais. No entanto, este pode ser acometido por adversidades, alterando seu curso típico. O estudo teve por objetivo realizar uma revisão sobre o conceito de estresse tóxico utilizado na Teoria do Ecobiodesenvolvimento de Shonkoff e analisar seus impactos no desenvolvimento humano. Foram realizadas buscas no PubMed, onde foram identificados 12 artigos conceituais para análise, no período de 2000 a 2013. Os resultados foram categorizados em eixos temáticos. A teoria

1 Universidade de São Paulo, Faculdade de Medicina de Ribeirão Preto, Hospital das Clínicas. Ribeirão Preto, SP, Brasil.

2 Universidade de São Paulo, Faculdade de Medicina de Ribeirão Preto, Departamento de Neurociências e Ciências do Comportamento. Av. Tenente Catão Roxo, 2650, Prédio da Saúde Mental, Salas 52/53, Campus Universitário Monte Alegre, 14048-900, Ribeirão Preto, SP, Brasil. Correspondência para/Correspondence to: M.B.M. LINHARES. E-mail: <linhares@fmrp.usp.br>.

Como citar este artigo/How to cite this article

Branco, M. S. S., \& Linhares, M. B. M. (2018). The toxic stress and its impact on development in the Shonkoff's Ecobiodevelopmental Theorical approach. Estudos de Psicologia (Campinas), 35(1), 89-98. https://doi.org/10.1590/1982-02752018000100009 
proposta por Shonkoff visa elucidar quais os impactos do estresse no desenvolvimento infantil, baseando-se em outras teorias do desenvolvimento. O estresse tóxico é uma ativação prolongada do corpo como resposta do sistema de estresse, que pode gerar, consequentemente, prejuízos neurobiológicos e psicológicos. As propostas de intervenções mostraram-se eficazes para minimizar os efeitos negativos desse tipo de estresse, assim como prover suporte aos cuidadores das crianças.

Palavras-chave: Desenvolvimento infantil; Saúde; Estresse.

Child development is characterized by quantitative and qualitative changes that follow a sequence and are relatively stable (Papalia \& Olds, 2000). These changes are interrelated with several biological, psychological, and social factors. Human development begins very early, since the conception, and depends on adult caregivers, who are mediators of child development because infants depend on parents or other primary caregivers for physical and emotional care.

Parenting is a process that occurs throughout child development. According to Barroso and Machado (2015), parenting represents parental care, which includes physical, emotional, and social aspects that are aimed to achieve healthy child development. Physical care is related to feeding, protection against injuries, hygiene, clothing for providing warmth, and others; emotional care includes parents' behaviors and attitudes that promote a sense of security and autonomy in the child, allowing him/her to have the capacity to take decisions; social care is associated with the capacity of caregivers to stimulate the insertion of the child in the social context, such as developing social abilities (Linhares, 2015). Thus, caregivers represent the main reference for the child, and therefore, they need to provide appropriate emotional and social support to ensure healthy child development.

The first relation with a child begins in the uterus, in which mother-child interactions are established. After birth, the child has the first contact with the microsystem of the family, which is the environmental context in which he/she will develop and will undergo positive or negative changes. These changes depend on several factors, including how the caregivers cope with life events (Solis-Ponton, 2004; Zornig, 2015).

Parents' ability to take care of their child depends on several factors (Barroso \& Machado, 2015). The Belsky's model (Belksy, 2005) proposes skills: individual factors of the parents, such as personality and psychopathology symptoms; individual factors of the child, such as temperament; and environmental factors, such as the social context, social support, relationships between parents, parents' professions, as well previous history of the parents. These factors could impact child development direct or indirectly.

Stressful events are expected during typical development, and children are often prepared to develop resources to cope with these adverse events through the relations with their parents (Wottrich \& Arpini, 2014). However, these relationships are not always positive such that they promote healthy development. Biological, psychological, economic, and social factors could negatively affect child development. Of these factors, we can identify poverty and negligence, mental health problems, low educational level, and alcohol and illegal substance abuses in parents, as factors that limit the resources to cope with the stress related to life adversities (Quartilho, 2012).

Children, who live in an environment that is filled with adversities, could exhibit abnormal development. Children exposed to stressful contexts showed higher cortisol levels (a hormone that regulates stress) than did children who were not (Slopen, McLaughlin, \& Shonkoff, 2014). Cortisol is related to specific areas of the central nervous system responsible for memory, learning, emotions, and the immunological system (Shonkoff, Richter, van der Gaag, \& Bhutta, 2012b). According to these authors, alterations in cortisol levels can lead to problems in the corresponding areas of child development, which persist throughout adulthood. This indicates that frequent exposure to stress events could contribute to the emergence of chronic diseases.

Injuries are also observed in the selfregulation process, learning, behavior, and physical 
and mental health. The emotional and behavioral regulation of children is initially mediated by their caregivers, which gradually leads to the emergence of self-regulation (Linhares, 2015). This process is essential for children to have the adequate capacity to tackle daily situations and to solve problems (Berger, 2011; Linhares \& Martins, 2015). Therefore, preventive interventions are effective for minimizing the impact of stress experiences on child development, moderating the negative effects in children and their caregivers under adverse contexts (Shonkoff, Dworkin, Leviton, \& Levine, 1979). Successful interventions with positive results are performed with the primary caregivers of children, particularly with parents. In this sense, a net of support is offered to parents who lack the personal resources to cope with the adversities in their environmental context (Schindler et al., 2015; Shonkoff \& Hauser-Cram, 1987).

The negative impact of intensive and continued stress on child development is well-known; consequently, there are demands of involvement of professionals in preventive interventions to protect the vulnerable children. Thus, the present study aimed to perform a thematic and integrative review of studies published on the concept of toxic stress, as proposed on the Ecobiodevelopmental Theory (EBD) proposed by the North-American developmental pediatrician named Jack Shonkoff, and to analyze the impact of stress on child development. Shonkoff is the coordinator of the Center on the Developing Child of Harvard University. The present review focused on answering the following questions: What is the definition of toxic stress?; What is the impact of stress on child development? How is the developmental approach is characterized in the EBD theory? What interventions for toxic stress have been proposed by Shonkoff? What is the theoretical framework of the EBD theory? and How does Shonkoff understand the function of parents and/or caregivers in human development?

\section{Method}

A search was performed on the PubMed database using the keyword "Shonkoff, J.P."
As inclusion criteria, the review focused only conceptual studies published during 2000 to 2013. Thesis, monographs, books, chapters, and empirical studies were excluded. Thirty-seven articles were found, and 12 studies that met the previously established inclusion and exclusion criteria were selected. The 12 articles were read, analyzed, and grouped along the following thematic axe: definition of toxic stress, impact of toxic stress on human development, theories related to the understanding of toxic stress and its consequences on human development, developmental approach in the Ecobiodevelopmental Theory, developmental regulation process, interventions proposed to reduce toxic stress and to prevent its negative consequences, and parents-child relationships and protective factors in child development.

\section{Results}

\section{Definition of toxic stress}

According to Shonkoff, stress, which can be experienced in early childhood, can be classified into three types (Garner et al., 2012; Shonkoff, 2010, 2012; Shonkoff \& Bales, 2011; Shonkoff, Boyce, \& McEwen, 2009; Shonkoff \& Levitt, 2010; Shonkoff et al., 2012a). The first type is positive stress, which is related to the psychological state with a short duration and of light to moderate intensity. Positive stress can be overcome when the children receive adequate support from caregivers. Thus, children recovering to the baseline level in the stress system. Positive stressful experiences are very common during childhood, for example, injection for immunization and anxiety associated with entering the school system. According to Shonkoff et al. (2012a), when the children have a stable environment with protective and supportive relationships, positive stressful experiences constitute challenges for the typical growth and development of children. These challenges are opportunities to learn adaptive responses face to negative and adverse experiences.

The second type is tolerable stress, that, contrary to positive stress, is associated to exposure 
to atypical experiences that present a higher level of adversity or threat to the individual (Garner et al., 2012; Shonkoff \& Bales, 2011; Shonkoff \& Levitt, 2010; Shonkoff et al., 2009, 2012b; Shonkoff, 2010, 2012); for example, death of a family member, a severe disease, natural disasters, or even terrorism acts. However, if children have a protective environment that supports them to cope with these events, the risks for short- and long-term psychological impact could be moderated and reduced. While facing tolerable stress, caregivers have to promote the protection of children through relationships that facilitate adaptive responses and a sense of control, reducing the physiological stress of the organism (Shonkoff et al., 2012a).

Finally, toxic stress is the third type of stress that is experienced by children. It is the most harmful event for child development, with negative consequences in several dimensions of life at short-, medium-, and long-term levels. Toxic stress is characterized by strong and frequent reactivity with prolonged activation of the organism to the stressful stimuli (Garner et al., 2012; Shonkoff, 2010; Shonkoff \& Levitt, 2010; Shonkoff et al., 2012a). Besides the higher level of arousal, toxic stress occurs in the absence of protective support for children from caregivers (Shonkoff, 2012; Shonkoff et al., 2012b). The risk factors, that were analyzed in the Adverse Childhood Experiences Study (ACE) (Gilbert et al., 2015) include multiple stressors, such as child abuse or negligence, abuse of illegal substances by parents, and maternal depression, which provoke a toxic stress response (Shonkoff et al., 2009; Shonkoff, 2010, 2012; Shonkoff \& Bales, 2011; Shonkoff \& Fisher, 2013). The ACEs study showed that the prevention of maltreatment against the children was effective in reducing later morbidity and mortality in adulthood.

Toxic stress could provoke a rupture in the cerebral circuit, as in other organs and metabolic systems, in important phases of human development (Shonkoff et al., 2012b). These changes could be relevant predictors of future problems in the development and learning in children, and in their physical and mental health, the negative effects of toxic stress experiences (Shonkoff et al., 2012).

\section{Impact of toxic stress on human development}

Toxic stress could impact development during early childhood; thus hampering biological and psychological development, and altering the cerebral structure and functionality. In addition, there are social problems associated with the toxic stress experiences (Shonkoff et al., 2009). Toxic stress causes hyperactivity in the neuronal pathways that control the child's fear response, thus resulting in a cerebral interpretation of threat and provoking aggressive responses as a defense (Shonkoff, 2000). In this sense, Shonkoff highlighted that children could develop post-traumatic disorders as consequence of repeated and prolonged significant experiences of violence.

According to Shonkoff (2010), the misfit cerebral development provokes injuries that could be expanded from infancy to adulthood, negatively influencing several aspects such as learning, behavior, and life expectancy. Additionally, the toxic stress could provoke the emergence of diseases in adulthood, as the adversities experienced during early infancy could be transformed into at-risk behaviors in the future. These behaviors are characterized by unhealthy lifestyle, such as abuse of illegal substances, fatherhood/motherhood in adolescence, and antisocial and violent behaviors. It is important to note that these behaviors could be the cause of stress in children who have parents with this type of lifestyle, and could also be a consequence of the toxic stress experienced in infancy (Shonkoff et al., 2012b). Children can also experience toxic stress at a very early stage of their development, i.e., in the uterus.

It is interesting to note that epigenetic studies showed that the alteration in the cerebral architecture caused by toxic stress could modify the individual's genetic expression, which, in turn, could be transmitted to the next generation (Bagot \& Meaney, 2010; Meaney, 2010; Meaney \& Szyf, 2005; National Scientific Council on the Developing 
Child, 2010; Szyf, McGowan, \& Meaney, 2008). As proposed by Garner et al. (2012), both the genetic predisposition and the environmental influence on gene expressions should be analyzed.

When the children experience toxic stress, besides the potential injuries mentioned above, "chronification" of the response to stress events could occur. Thus, children may react with intense responses to adverse events that usually happen in their life, revealing a response that is more aggressive than expected (Shonkoff et al., 2012b).

\section{Theories related to the understanding of toxic stress and its consequences on human development}

Shonkoff used theories from several fields ranging from Biology to Social Sciences, including principles of Political Theory, to support the definition of toxic stress and its impact on the health of individuals and the society (Garner et al., 2012; Shonkoff, 2000, 2003, 2010, 2012; Shonkoff \& Bales, 2011; Shonkoff \& Fisher, 2013; Shonkoff \& Levitt, 2010; Shonkoff et al., 2009, 2012a, 2012b).

The Ecobiodevelopmental Theory model of Shonkoff is associated directly to other theoretical models of human development. The first one is the Transactional of Development Model, proposed by Sameroff (Sameroff \& Chandler, 1975; Sameroff \& Fiese, 2000). In this model, the child development is conceptualized as a product of interactions that happen continuously and dynamically in the familial context and in the broad social context. The second one is the Socioecological Model of Bronfenbrenner (1996), in which development is considered to occur though processes of reciprocal interactions that become progressively more complex with regard to the relationships in the familial micro context to those in the macro context of culture. Finally, the influence of the theory of Psychopathology of Development could be noted in the EBD model, though the studies of Rutter (2000) about the risk factors and protective mechanisms of development, and the concept of resilience. This last concept shows that stress coping and overcoming of adversities occurs in individuals who reach adaptive developmental outcomes by facing adversities and stressful events.

According to Shonkoff et al. (2012b), the EBD theoretical model proposes to understand the biological mechanisms that explain the strong relations between adversities faced during infancy and their consequences to development during adulthood. This approach is innovative in that it highlights the relevance of re-thinking the basic conceptions for health promotion and prevention of diseases based on the integration of development across the life span, i.e., from conception till death. This model explains the demand to create policies to prevent negative outcomes in individuals exposed to adversities in infancy (Shonkoff, 2010). Studies that focus on the individual differences in examining biological sensitivity to stress effects could better explain how children, who were exposed to adverse contexts, respond better to specific interventions than others do.

The adversities associated with the absence of protective relationships are related to the concept of "biological memories". Based on the EBD model, toxic stress experiences provoke these memories, which are essentially created by interactions between the individual's genes and environment, and these could begin at the pre-natal phase (Garner et al., 2012). Then, focusing the adversities experienced in infancy, the EBD model proposes that: 1) the toxic stressful experienced in early childhood are very critical because they can weaken the development of adaptive capacities and abilities of coping with future challenges; 2 ) the prevention of adverse consequences in the long-term are minimized by stable and protective relationships with caregivers, which support the children to develop a sense of security. In the context of this type of relationships, children react to the stress events and recover to the basal-state (Garner et al., 2012). The EBD model postulates that the presence of adversities, and the absence or insufficiency of protective relationships to help children to reach a healthful response to stressful events could result in damages and losses to development in adulthood. 


\section{The developmental approach in the Echobiodevelopmental theory}

It is remarkable that the concerns of Shonkoff's theory about the human development, mainly those regarding the problems experienced in early childhood, could provoke negative consequences during adulthood. Consequently, the prevention of the damages associated with toxic stress experiences is essential for healthy development. Further, the scientific advances offer strong evidence about the influence of environmental experiences not only on behavior, but also on the modification of genes and of the neurobiological system (Shonkoff et al., 2012a).

The toxic stress experienced during infancy enhances the risk for developing physical and mental diseases, cognitive deficits, and difficulties to deal with future stressful events in adulthood (Shonkoff, 2003; Shonkoff \& Levitt, 2010). These problems and risk factors for diseases occur during sensitive periods, when the cerebral development is more vulnerable to positive or negative environmental stimuli (Shonkoff et al., 2009; Shonkoff \& Bales, 2011).

A solid and healthy physical and mental base during early childhood is an indispensable requirement for wellbeing during adulthood, which is essential for beneficial and harmonic relationships in the society and for economic productivity. The overload of adversities experienced during infancy could be difficult to revert during adulthood, otherwise, a "good beginning" at the early ages could help develop abilities to cope successfully with adverse situations during adulthood, and could contribute in a productive way to the society. Thus, it is necessary to support children to have a "good beginning" in life (Shonkoff et al., 2012b).

\section{Regulation of the developmental process}

The capacity of regulating the process of child development could be affected by toxic stress (Shonkoff, 2010, 2012). This capacity influences several areas of development, such as language, cognition, and social skills. The stress hormone act exposure to this hormone could hamper the regulation of physiological mediators that provoke a wear and tear in several systems and organs, including the brain (Shonkoff \& Levitt, 2010; Shonkoff et al., 2012a). This hormonal imbalance harms executive functions, decision-making ability, working memory, behavioral self-regulation, and control of impulse.

Self-regulation allows that other relevant abilities can be developed as expected. For example, it is expected that the children enhance their reading ability, but it is also necessary that the children enhance their emotional and social abilities to regulate their behavior (Shonkoff, 2003). The emotional and behavioral regulation processes are relevant dimensions for the developmental self-regulation process, which helps children and adults to deal effectively with adversities, and helps children to have good school performance. In the school, the children need to have optimal concentration, attention, emotional monitoring, and control of impulses, such that they can follow rules and attend to different demands. The teachers need to contribute to the development of a strong base of several abilities in children, such as executive functions and self-regulation. It is therefore necessary to examine the individual differences in self-regulation to identify effective ways to support the teaching-learning processes (Shonkoff 2012; Shonkoff \& Fisher, 2013).

The changes provoked by stressful experiences remodel the neuronal and connectivity structure that, in turn, could affect a diversity of behavioral, emotional, and physiological responses such as anxiety, aggression, mental flexibility, and memory. When there is a prolonged activation of stress, the brain becomes programmed to adapt to adverse environments. Thus, a low tolerance to stress experiences and a high risk for aggressive behavior develops (Shonkoff et al., 2012b).

\section{Interventions proposed to reduce toxic stress and to avoid negative consequences on development}

According to Shonkoff's theory (Shonkoff, 2010), the development of intervention programs 
is essential to provide social support to families and, consequently, to children who live in adverse environments. In the United States of America, Skonkoff (2000) mentioned examples of intervention programs, such as Head Start (Raikes \& Emde, 2006), which was created to support children to have better health conditions, and to develop their school and reading competences and performances.

Head Start (Gonzalez-Mena, 2009), Perry Preschool Project (Schweinhart, 2005), and Abecedarian Program (Campbell et al., 2012) are successful initiatives with positive results, as highlighted by Shonkoff $(2000,2010)$. These programs promote changes in the development trajectory of vulnerable children. These programs should be adapted to different cultures, ethnicities, and social classes (Shonkoff, 2003). Another effective intervention program is the Tools of the Mind (Bodrova \& Leong, 2007), which was developed to promote behavior, cognition, and neural mechanisms of self-regulation in children (Knudsen, Heckman, Cameron, \& Shonkoff, 2006; Shonkoff \& Fisher, 2013).

The investment on intervention programs to protect the development of vulnerable children at early ages is more economical because such programs reduce future expenditure on taking care of adults with chronic diseases and unhealthy habits that are consequences of toxic stress experiences since in infancy. Concerning the role of adult caregivers, it is essential that the programs also support the caregivers, and offer information and training to help them take appropriate care of their children. In this sense, we can create a net of support for both children and caregivers. According to Shonkoff et al. (2012a), the base of the construction of these social support nets could be grouped into the following three categories: 1) time and commitment; 2) financial, psychological, social, and institutional resources; 3 ) and capacity and knowledge. The net of support could be created through co-participation between public and private sectors, building indispensable conditions for caregivers to take care of children adequately. For example, they can be provide paid vacation, time for breastfeeding infants during working hours, flexible work hours to visit a pediatrician and to attend school meetings of children, etc. (Shonkoff et al., 2012a).

It is important to note that, as expected, the children experience some degree of stress throughout the childhood; however, the caregivers should be capable to avoid these stressful experiences from turning into toxic stress. In this sense, it is necessary to have a net of support for parents aiming to support them to adopt positive and adequate strategies to promote the children's learning of social, emotional, and communicative abilities. Then, there are intervention programs in the United States, such as Incredible Years (WebsterStratton, 2005) and Home Visiting (Council on Community Pediatrics, 2009), which include the promotion of " $7 \mathrm{Cs}$ " of resilience, i.e., competence, confidence, connection, character, contribution, coping, and control (Garner et al., 2012).

\section{The parent-child relationship and protective factors of child development}

The essential characteristics of the familial context, which influence child development, are the social relationships with the primary caregiver (Shonkoff, 2003). The relationships between parents and children, and their support system, are essential aspects for the acquisition of healthy development. However, frequently, the risky situations that the children are exposed to often stem from the experiences of parents and primary caregivers who are also vulnerable and less able to support and protect the children during early ages (Shonkoff et al., 2012b). According to Shonkoff (2010), the majority of children, who experienced toxic stress, have high probability to have caregivers living under extreme poverty condition with maltreatment, violence, maternal depression, and/or abuse of illicit substances. Aggravating this scenario, there is a low chance that these caregivers seek support services; also there is a high risk of abandonment of assistance of the services (Shonkoff et al., 2009). Besides, these parents and primary caregivers are less exposed to orientation and knowledge about 
child development, since in many homes, the parents have a low educational level and present difficulties in using strategies to cope with stress experiences of the environment that they live in, such as poverty, violence, and inappropriate homes and neighborhoods (Shonkoff, 2010).

According to Shonkoff et al. (2012b), cerebral development is built on the interaction between genes and environmental factors, which is strongly influenced by the mutual relations between adults and children, mainly in the beginning years of development. Consequently, the interventions at infancy should include several components of support of health services, learning opportunities with parental education, and emotional and social support for families. Despite the negative effects of the toxic stress in the long term, there is little attention to the creation of strategies for promotion of health and prevention of diseases that would reduce the exposure to stress in children and their families (Shonkoff et al., 2009; Shonkoff, 2012). Some programs focused teaching parents to stimulate the children at early ages through reading and playing (Shonkoff \& Fisher, 2013). As highlighted by these authors, the positive and enriched experiences at early development enhance the cognitive and emotional functioning and the coping strategies in stressful conditions. However, there is a limited impact of these programs in children who were already exposed to stressful experiences and have neurological damages that negatively affect the learning process.

\section{Final Considerations}

Toxic stress causes a strong, frequent, and prolonged activation of the organism, which is a response to the stress system. In general, it is associated to the absence of protective relationships of adult caregivers. The negative impact of toxic stress could be detected on several areas of development, such as learning, self-regulation, and high predisposition to develop chronic diseases in adulthood.

Preventive interventions should target both children and caregivers, because the toxic stress could be reduced and/or eliminated. These interventions are relevant considering that the mains focus is more on the prevention and assistance of the children in early childhood, and their caregivers, than only on diseases and treatments. Health and educational professional should be trained to see the children based on the principles of integrality and dynamic bidirectional relationship between children and their environmental contexts. Then, they could be capable to identify potential damages to the child development and support parents and/or other caregivers of children.

The Ecobiodevelopmental Theory presents great applicability and generalization in Brazilian context because there are toxic stressful events in several contexts of child development. Therefore, Brazilian researchers could apply the concepts of Shonkoff's theory to support prospective-longitudinal empirical studies for deeply understanding of the toxic stressful experiences and their impacts on the human development. Stress is a relevant problem for public health, it is therefore very useful to propose public policies to promote and protect efficiently the child development and health.

\section{Contributors}

All authors participated in all phases of the research article.

\section{References}

Bagot, R. C., \& Meaney, M. J. (2010). Epigenetics and the biological basis of gene $X$ environment interactions. Journal American Academy of Child and Adolescent Psychiatry, 49(8), 752-771. https://doi.org/10.1016/j. jaac.2010.06.001

Barroso, R. G., \& Machado, C. (2015). Definições, dimensões e determinantes da parentalidade. In G. A. Pluciennik, M. C. Lazzari, \& M. F. Chicaro (Orgs.), Fundamentos da família como promotora do desenvolvimento infantil: parentalidade em foco (pp. 16-32). São Paulo: Fundação Maria Cecília Souto Vidigal.

Belsky, J. (2005). Social-contextual determinants of parenting. In R. E. Tremblay, R. G. Barr, \& R. V. Peters (Eds.), Encyclopaedia on early childhood development. 
Montreal: Centre of Excellence for Early Childhood Development (pp. 1-6). Available from: http://www. child-encyclopedia.com/sites/default/files/textesexperts/en/654/social-contextual-determinants-ofparenting.pdf

Berger, A. (2011). Self-regulation: Brain, cognition, and development. Washington: American Psychological Association.

Bodrova, E., \& Leong, D. (2007). Tools of the mind: A Vygotskian approach to early childhood education (2nd ed.). New York: Pearson.

Bronfenbrenner, U. A. (1996). A ecologia do desenvolvimento humano: experimentos naturais e planejados. Porto Alegre: Artes Médicas.

Campbell, F. A., Pungello, E. P., Burchinal, M., Kainz, K., Pan, Y., Wasik, B. H., ... \& Ramey, C. T. (2012). Adult outcomes as a function of an early childhood educational program: An Abecedarian Project followup. Developmental Psychology, 48(4), 1033-1043. https://doi.org/10.1037/a0026644

Council on Community Pediatrics (2009). The role of preschool home-visiting programs in improving children's developmental and health outcomes. Pediatrics, 123(2), 598-603. https://doi.org/10.1542/ peds.2008-3607

Garner, A. S., Shonkoff, J. P., Siegel, B. S., Dobbins, M. I., Earls, M. F., McGuinn, L., ... \& Wood, D. L. (2012). Early childhood adversity, toxic stress, and the role of the pediatrician: Translating science into lifelong health. Pediatrics, 129(1), 224-231. https://doi.org/10.1542/ peds.2011-2662

Gilbert, L. K., Breiding, M. J., Merrick, M. T., Thompson, W. W., Ford, D. C., Dhingra, S. S., \& Parks, S. (2015). Childhood adveristy and adult chronic disease. American Journal of Preventive Medicine, 48(3), 345-349. https:// doi.org/10.1016/j.amepre.2014.09.006.

Gonzalez-Mena, J. (2009). Child, family, and community (5th ed.). Hoboken, NJ: Pearson Education.

Knudsen, E. I., Heckman, J. J., Cameron, J. L., \& Shonkoff, J. P. (2006). Economic, neurobiological, and behavioral perspectives on building America's future workforce. Proceedings of the National Academy of Science of the United States of America, 103(27), 10155-10162. https://doi.org/10.1073/pnas.0600888103

Linhares, M. B. M. (2015). Família e desenvolvimento na primeira infância: processo de autorregulação, resiliência e socialização de crianças pequenas. In G. A. Pluciennik, M. C. Lazzari, \& M. F. Chicaro (Orgs.), Fundamentos da família como promotora do desenvolvimento infantil: parentalidade em foco (pp. 70-82). São Paulo: Fundação Maria Cecília Souto Vidigal.

Linhares, M. B. M., \& Martins, C. B. S. (2015). O processo da autorregulação no desenvolvimento de crianças. Estudos de Psicologia (Campinas), 32(2), 281-293. https://doi. org/10.1590/0103-166X2015000200012
Meaney, M. J. (2010). Epigenetics and the biological definition of gene $x$ environment interactions. Child Development, 81(1), 41-79. https://doi.org/10.1111/ j.1467-8624.2009.01381.x

Meaney, M. J., \& Szyf, M. (2005). Environmental programming of stress responses through DNA methylation: Life at the interface between a dynamic environment and a fixed genome. Dialogues in Clinical Neuroscience, 7(2), 103-123.

National Scientific Council on the Developing Child (2010). Early experiences can alter gene expression and affect long-term development. Working Paper, 10, 1-12. Retrived November 16, 2016, from http:// www.developingchild.net

Papalia, D. E., \& Olds, S. W. (2000). Desenvolvimento Humano (7a ed). Porto Alegre: Artmed.

Quartilho, M. (2012). A infância dura toda a vida sobre a importância e o impacto das experiências de adversidade precoce. Revista da Sociedade Portuguesa de Medicina Física e de Reabilitação, 22(2), 49-52. Recuperado em novembro 24, 2016, de http:// spmfrjournal.org/index.php/spmfr/article/view/13/13

Raikes, H. H., \& Emde, R. (2006). Early Head Start: A bold new program for low-income infants and toddlers. In N. F. Watt, C. Ayoub, R. H. Bradley, J. E. Puma, \& W. A. LeBoeuf (Eds.), The crisis in youth mental health: Critical issues and effective programs (pp. 181-206). Westport, CT: Praeger.

Rutter, M. (2000). Resilience reconsidered: Conceptual considerations, empirical findings, and policy implications. In J. P. Shonkoff, \& S. J. Meisels (Eds.), Handbook of early childhood intervention (2nd ed., pp. 6551-6682). New York: Cambridge University Press.

Sameroff, A. J., \& Chandler, M. J. (1975). Reproductive risk and the continuum of caretaking casualty. In F. D. Horowitz, M. Hetherington, S. Scarr-Salapatek, \& G. Sigel (Eds.), Review of child development research (Vol. 4, pp. 187-244). Chicago: University of Chicago Press.

Sameroff, A. J., \& Fiese, B. H. (2000). Transactional regulation: The developmental ecology of early intervention. In J. P. Shonkoff, \& S. J. Meisels (Eds.), Handbook of Early Childhood Intervention (2nd ed., pp. 135-150). New York: Cambridge University Press.

Schindler, H. S., Kholoptseva, J., Oh, S. S., Yoshikawa, H., Duncan, G. J., Magnuson, K. A., \& Shonkoff, J. P. (2015). Maximizing the potential of early childhood education to prevent externalizing behavior problems: A meta-analysis. Journal of School Psychology, 53(3), 243-263. https://doi.org/10.1016/j.jsp.2015.04.001

Shonkoff, J. P. (2000). Science, policy, and practice: Three cultures in search of a shared mission. Child Development, 71(1), 181-187.

Shonkoff, J. P. (2003). From neurons to neighborhoods: Old and new challenges for developmental and 
behavioral pediatrics. Journal of Developmental and Behavavioral Pediatrics, 24(1), 70-76. https://doi. org/10.1097/00004703-200302000-00014

Shonkoff, J. P. (2010). Building a new biodevelopmental framework to guide the future of early childhood policy. Child Development, 81(1), 357-367. https:// doi.org/10.1111/j.1467-8624.2009.01399.x

Shonkoff, J. P. (2012). Leveraging the biology of adversity to address the roots of disparities in health and development. Proceedings of the National Academy of Science of the United States of America, 109(2), 17302-17307. https://doi.org/10.1073/ pnas. 1121259109

Shonkoff, J. P., \& Bales, S. N. (2011). Science does not speak for itself: Translating child development research for the public and its policymakers. Child Development, 82(1), 17-32. https://doi.org/10.1111/ j.1467-8624.2010.01538.x

Shonkoff, J. P., Boyce, W. T., \& McEwen, B. S. (2009). Neuroscience, molecular biology, and the childhood roots of health disparities: Building a new framework for health promotion and disease prevention. Journal of the American Medical, 301(21), 2252-2259. https:// doi.org/10.1001/jama.2009.754

Shonkoff, J. P., Dworkin, P. H., Leviton, A., \& Levine, M. D. (1979). Primary care approaches to developmental disabilities. Pediatrics, 64(4), 506-514.

Shonkoff, J. P., \& Fisher, P. A. (2013). Rethinking evidencebased practice and two-generation programs to create the future of early childhood policy. Development and Psychopathology, 25(4Pt.2), 1635-1653. https://doi. org/10.1017/S0954579413000813

Shonkoff, J. P., Garner, A. S., Siegel, B. S., Dobbins, M. I., Earls, M. F., McGuinn, L., ... \& Wood, D. L. (2012a). The lifelong effects of early childhood adversity and toxic stress. Pediatrics, 129(1), 232-246. https://doi. org/10.1542/peds.2011-2663

Shonkoff, J. P., \& Hauser-Cram, P. (1987). Early intervention for disabled infants and their families: A quantitative analysis. Pediatrics, 80(5), 650-658.
Shonkoff, J. P., \& Levitt, P. (2010). Neuroscience and the future of early childhood policy: Moving from why to what and how. Neuron, 67(5), 689-691. https://doi. org/10.1016/j.neuron.2010.02.032

Shonkoff, J. P., Richter, L., van der Gaag, J., \& Bhutta, Z. A. (2012b). An integrated scientific framework for child survival and early childhood development. Pediatrics, 129(2), 460-472. https://doi.org/10.1542/ peds.2011-0366.

Schweinhart, L. J. (2005). Lifetime effects: The High-Scope Perry Preschool Study through age 40. Ypsilanti, MI: High Scope Press.

Slopen, N., McLaughlin, K. A., \& Shonkoff, J. P. (2014). Interventions to improve cortisol regulation in children: A systematic review. Pediatrics, 133(2), 312-326. https://doi.org/10.1542/peds.2013-1632

Solis-Ponton, L. (Org.). (2004). Ser pai, ser mãe. Parentalidade: um desafio para o terceiro milênio. São Paulo: Casa do Psicólogo.

Szyf, M., McGowan, P., \& Meaney, M. J. (2008). The social environment and the epigenome. Environmental and Molecular Mutagenesis, 49(1), 46-60. https://doi. org/10.1002/em.20357

Webster-Stratton, C. (2005). The Incredible Years: A trouble-shooting guide for parents of children aged 2-8 years. Seattle, WA: Incredible Years.

Wottrich, S. H., \& Arpini, D. M. (2014) Cuidados necessários à infância: um estudo com mães coletadoras de material reciclável. Temas em Psicologia, 22(2), 471-482. https://doi.org/10.9788/TP2014.2-16

Zornig, S. M. A. J. (2015). Parentalidade: uma via de mãe dupla. In G. A. Pluciennik, M. C. Lazzari, \& M. F. Chicaro (Orgs.), Fundamentos da família como promotora do desenvolvimento infantil: parentalidade em foco (pp. 48-57). São Paulo: Fundação Maria Cecília Souto Vidigal.

Received: May 24, 2016

Final version: December 2, 2016

Approved: January 31, 2017 